\title{
A Critical Study of Children Under Juvenile Justice System in
} India

\author{
Venudhar Routiya \\ Assistant Professor, School of Studies in Law, Pt. Ravishankar Shukla University, Raipur (C.G.) India
}

\begin{abstract}
This paper is based on a research project of Ph.D. on title "A Critical and Comprehensive Study of Children under Juvenile Justice Act." Juvenile Justice System is most dynamic and illuminated framework embraced by the world citizenry with all round development of children. The prime center is to change the degenerates and give consideration to the unprotected children. To the extent practicable, a child to be rehabilitee and reestablished to the family. [1] The article assessed the Juvenile Justice System in India in the light of protected reasoning and International parameters. Various adults today have this thoroughly Aristotelian beginning of pre-adulthood without having truly examined any of Aristotle. It instructs their understanding of their own relationship toward the adolescents around them. In this way they consider the fundamental commitment they bear toward their youths to be the dedication to give the kind of enduring environment those children need to frame into regular adults, with the common and mental structures set up anticipated that would play out the limits we acknowledge that normal, standard adults can perform.[2] John Locke, by separation, keeps up that the human identity begins as a "white paper, depleted of all characters, without any contemplation. On this view each one of the "materials of reason and learning" starts in actuality. Locke's foreswearing of the instructing of intrinsic considerations was, certainly, organized especially at Descartes and the Cartesians. However, it moreover recommends a release of the Platonic tradition that learning is a memory of definitely known Forms. A couple of researchers of mental change today fined either the colossal impelling of Locke or the strong inmates of Plato or Descartes absolutely agreeable. [3] According to what we have called the "Aristotelian start", youth is a fundamentally up and coming state. On such a point of view, the estimation of what a child produces can't be required to be extraordinary in it, however, valuable for helping the child to shape into a fair adult. Possibly some child craftsmanship is a counterexample to this yearning. Clearly, one could battle that adults, who, as children, were encouraged to convey workmanship, and what's more make music and surpass desires at redirections, will most likely be succeeding adults than the people who are not asked to give such "outlets" to their imperativeness and imaginativeness. Regardless, the instance of child craftsmanship should in any occasion make one suspicious of Michael Slote's case that "essentially as dreams are discounted except for as they impact (the waking parts of) our lives, what happens in youth predominantly impacts our point of view of total lives through the effects that puberty accomplishment or frustration ought to have on adults individuals" [4]

Keywords: Children's Rights, Juvenile Justice System, Constitutional Law.
\end{abstract}

Definition of Child:-

\section{Introduction}

Describing what age a man is or ceases to be a child is an unfaltering common contention in the India. The Census of India considers adolescents to be any person underneath the age of 14, as do most government activities. Actually, pre-adulthood is the stage amongst early stages and adulthood. As demonstrated by the UNCRC 'a youth means every individual underneath the age of eighteen years unless, under the law pertinent to the child, the overwhelming part is accomplished some time recently'. This significance of a youth considers solitary countries to choose as showed by the own alert the age uttermost compasses of a child in their own specific laws. In any case, in India, diverse laws related to youths portray children in different age limits.

The Indian Penal Code (IPC) 1860 finds that no youthful underneath the age of seven may be considered criminally in charge of advancement (Sec 82 IPC). By uprightness of mental impediment or frailty to fathom the after effects of one's exercises the criminal obligation age is raised to twelve years (Sec 83 IPC). A young woman must be no under sixteen years remembering the deciding objective to give sexual consent, unless she is hitched, in which case the reinforced age is no less that fifteen. Regarding security against finding, getting, and related offenses the given age is sixteen for energetic associates and eighteen for young women. [5]

As showed up by Article 21 (A) of the Indian Constitution, "the State shall provide free and compulsory education to all children of the age of six to fourteen years in such manner as the State may, by law, determine." Article 45 states that "the State shall endeavor to provide early childhood care and education for all children until they complete the age of six years". At long last Article $51(\mathrm{~A})(\mathrm{k})$ states "who is a parent or 
guardian to provide opportunities for education to his child or, as the case may be, ward between the age of six and fourteen years".[6]

The Child Labor (Prohibition and Regulation) Act, 1986 defines a child as a man who has not completed fourteen years of age.[7] The Factories Act, 1948 and Plantation Labor Act 1951 states that a child is one that has not completed fifteen years of age and a juvenile is one who has completed fifteen years of age yet has not completed eighteen years of age. According to the Factories Act, young people are allowed to work in handling plants the length of they are regarded therapeutically fit yet may not for more than four and half hours a day.[8]

The Motor Transport Workers Act 1961, and The Beedi and Cigar Workers (Conditions of Employment) Act 1966, both portray a child as a man who has not completed fifteenth years and fourteenth years of age respectively. [9] The Merchant Shipping Act 1958 and Apprentices Act 1961 don't describe a youth, yet in acquirements of the acting state that a child underneath fourteen is not permitted to work in occupations of the appear. [10] The Mines Act, 1952 is the significant trade-related act that depicts an adult as a man who has completed eighteen years of age (thusly a child is a man who has not completed eighteen years of age). [11]

The Prohibition of Child Marriage Act, 2006 states that a male has not master lion's offer until he is twenty-one years of age and a female has not capable larger part until she is eighteen years of age. [12] The Indian Majority Act, 1875 was supported to make a clearing noteworthiness of a minor for such goes about as the Guardians and Wards Act of 1890. Under the Indian Majority Act, 1875 a man has not refined greater part until he or she is of eighteen years of age. This monstrosity of a minor moreover stays for both the Hindu Minority and Guardianship Act, 1956 and the Hindu Adoption and Maintenance Act, 1956. Muslim, Christian, and Zoroastrian individual law in like path keep up eighteen as the period of lion's offer. [13] The major Juvenile Justice Act, 1986 delineated boys as underneath sixteen years of age and a young woman child as underneath eighteen years of age. [14] The Juvenile Justice (Care and Protection of Children) Act, 2000 has changed the essentialness of adolescent to any person who has not completed eighteen years of age. [15] However, new correction the Juvenile Justice (Care and Protection of Children) Act, 2015 provides for a child in conflict with the law who is age group 16-18 years of age to be decided as adults for heinous offenses such as rape and murder and other 21 types of crimes. Heinous offenses are those which are punishable by imprisonment of seven years or more. [16]

By virtue of its umbrella procurements and because it is the latest law to be approved as for child rights and certification, various are of the evaluation that the importance of a child found in the Juvenile Justice Act, 2015 should be seen as the legal significance of a child in all matters.

\section{Debates of Juvenile Justice Act, 2015 in India}

The whole discussion in regards to 'who is a child', conceding in an another significance, has sprung up once again by the Supreme Court on 11th January 2016 supporting the Parliament to view more "thorough" sentence for child sex abuse offenders. The point, as the Supreme Court has noted, is the determination of "children" under the Indian Penal Code. At present, "child" is characterized in the IPC as 'any person under the age of $18^{\prime}$ and there is no group of children as a child as a few years and different minors with regards to an assault. [17]

The Hon'ble court in the said case suggested the example of Lakshmi Kant Pandey v. The Union of India, of the Hon'ble Supreme Court wherein the Apex Court watched that children are "particularly imperative national asset" and the future flourishing of the nation depends on upon how its children create and make. From the judgment, it was obvious that it was preferable to Article 21, as the solicitation was under Article 32 and reference to Article 15(3) and 24 were in help thereof. The Court recognized the benefit to a home, a name, and a family as a part of the "right to life". While dealing with a practically identical issue which had developed as here, the Kerala High Court because of Philips Allred Malvin v. Y.J. Gonsalves and others, while considering the Canon Law as material to various classes of Christians, has held that the benefit of the couple to grasp a child is a secured right guaranteed under Article 21 as the right to life combines those things which make life essential.[18]

The cut-off age for an adolescent reprobate charged for heinous crimes, for the time, came under certain open deliberation when on 31 December 2015 the President gave his consent to the Juvenile Justice (Care and Protection of Children) Bill, 2014. On 15th January 2016 is notified the new Act of 2015. It has now made ready for the trial of a few children somewhere around 16 and 18 years charged for heinous crimes as adults, in view of a preparatory evaluation of their mental and physical limit, circumstances in which the offense was supposedly dedicated and their capacity to understand the outcomes of the offense.

Discussions in the media and Parliament had as their edge of reference, young people required in homicide, murder as well as rape and sexual crime. 
What ought to have been of more profound concern was the means by which and why children get included in heinous crimes and what are the safety crevices on the ground in the group to keep children from being maltreated, abused, and tortured. Take the case of youths who are a piece of furnished gatherings working in Naxal territories.

Amid the Eastern Region Round Table Conference on the Effective Implementation of the JJ Act in 2015, held under the aegis of the one-man Supreme Court council on juvenile justice, the effect of insurrection on children in Chhattisgarh and Jharkhand came into sharp core interest.

What ought to the state's reaction be towards such children? Without a doubt, the equipped gatherings won't quit selecting children somewhere around 16 and 18 years since they can now be attempted as adults. The misuse of their defenselessness, truth be told, begins much prior.

In June 2015, the secretary general, in his report to the Security Council, definite the usual Operandi of armed groups in Bihar, Chhattisgarh, Jharkhand and Odisha who initiate 6 to 12-year-old children, train them as sources and grant preparing of rough weapons. The children are then moved into particular units for preparing on the utilization of weapons and ad-libbed hazardous gadgets.

The report additionally noticed that "children are supposedly debilitated with the executing of relatives if they escape or surrender to security strengths". This likewise holds useful for youngsters in specific parts of our urban communities who are included in packs and constrained into carrying out burglary, theft, drugtrafficking and savage crimes.

The new law characterizes 'deplorable offense' comprehensively to incorporate "offenses for which the base discipline under the Indian Penal Code (IPC) or some other law until further notice in power is detainment for a long time or more".

In view of this definition, there are no less than 46 offenses under which youngsters in conflict with the law can be attempted as grown-ups. This incorporates offenses like trafficking, share passing, corrosive assaults, theft or dacoity with an endeavor to bring about hurt or an outfitted weapon under the IPC.

Offenses under the Narcotic Drugs and Psychotropic Substances Act, 1985 (NDPS Act) that criminalize ownership, deal, buy, transport of business amount of specific medications like poppy straw, opium poppy, cannabis and psychotropic substances likewise fall under the ambit of this definition.

The utilization of denied arms, enrollment to an unlawful affiliation, and investment in a terrorist demonstration are likewise offenses for which a few youths somewhere around 16 and 18 years can be attempted as grown-ups.

The officials accepted that youthful persons are self-governing creatures equipped for settling on a discerning choice like submitting a demonstration of dread, hawking drugs, or conferring group assault. This is deceptive given the moderate development of the pre-adult cerebrum, the inadequacy of youthful persons to remove themselves from standoffish circumstances, the absence of foreknowledge, and their weakness to impact.

The JJ Act, 2015, criminalizes the enlistment or utilization of any youngster for any reason by a nonstate, so called aggressor bunch, or any grown-up or grown-up gathering utilizing children for unlawful exercises. It likewise criminalizes the utilization of a child for distributing, hawking, conveying, supplying or pirating inebriating alcohol, opiate drugs or psychotropic substances.

In a study appointed by the National Commission for Protection of Child Rights and did by National Drug Dependence Treatment Center (NDDTC) and All India Institute of Medical Sciences (AIIMS) on substance misuse among youngsters in India, a dominant part of the 4,024 surveyed reported having utilized an assortment of substances, for example, tobacco, liquor, cannabis and inhalants. Presentation to medications happens inside the family, as 60.1 percent of out-of-school children and 51.6 percent of school-going children had a relative utilizing substance. [19]

Reaffirming the associated impact variable, 82.4 percent children imparted that they had close contact with companions utilizing substances and 40.6 percent referred to companion weight as a component that kept them from stopping. The concentrate additionally uncovered that 18 percent of youngsters living in homes and 29 percent of children in the city "enjoyed sexual conduct under the impacts of substance; 16.9 percent and 20 percent (individually) enjoyed sexual conduct in return for either substances or cash. [20]

Around 38.7 percent of children in the city and 15.9 percent of children living in homes confessed to having "accomplished something hazardous to acquire cash or get nourishment, garments, cover". A larger part of the children expressed that they had not connected for help (67.7 percent) and a hazardously extensive number (43.8 percent) felt they didn't require any assistance.

In what capacity ought to the law view children who are caught by their dependence and submit a shocking offense to encourage their propensity? At last, in what manner would it be a good idea for us to manage a 17-year-old child egged on by grown-ups around him to demonstrate his masculinity by assaulting girls? [21] 
While there is nothing child-like about assault or brutality of any sort, evaluation of a 'child-like or grown-up like personality' in this setting is similarly foolish. The inquiry truly is whether we can force the same level of culpability upon youths whose brains have not completely created and who do not have the neurological brakes to keep them from following up on the drive in extremely charged circumstances. The wounds they incur might be the same yet their culpability is most certainly not.

By passing the JJ Act, 2015, Parliament has definitely deprived youths of the insurance they have to hold over a transient and turbulent period of their lives. Rather than fortifying the responsibility components of the adolescent equity framework and escalating preventive endeavors, it has given into the disdain wave against adolescents. It organizes revenge over counteractive action, advising, medicinal treatment, security and mending. [22]

\section{What are the Child Rights?}

\section{Child Rights and Child Protections}

A benefit is an essential or contract developed between the persons who hold a benefit (consistently implied as the "rights-holders") and the persons or associations which then have responsibilities and commitments in association with the affirmation of that benefit (as often as possible suggested as the "commitment bearers".) Child rights are specific human rights that apply to each and every person underneath the age of 18 years.

For the most part, child rights are described by the United Nations and United Nations Convention on the Rights of the Child (UNCRC). As showed by the UNCRC Child Rights are slightest capabilities and opportunities that should remain to all persons underneath the age of 18 paying little notice to race, shading, sexual introduction, vernacular, religion, evaluations, sources, wealth, birth status or limit and thus apply to all people all around. The UN finds these rights related and fearless, inferring that a benefit cannot be fulfilled to the impairment of another benefit.

The inspiration driving the UNCRC is to plot the principal human rights that should have remained to youths. There are four far-reaching game plans of these rights. These four arrangements cover all aware, political, social, money related and social benefits of every child.

Right to Survival: A child's privilege to survival begins before a tyke is imagined. As demonstrated by Government of India, a tyke life begins taking after twenty weeks of the start. Thus the benefit to survival is far reaching of the adolescent rights to be imagined, the benefit to minimum measures of sustenance, safe house, and clothing, and the benefit to living with deference.

Right to Protection: An adolescent has the benefit to be protected from carelessness, abuse and mistreat at home, and elsewhere.

Right to Participation: An adolescent has a benefit to sharing in any essential authority that incorporates $\mathrm{him} / \mathrm{her}$ direct or roundabout. There are changing degrees of the venture as indicated by the age and improvement of the child.

Right to Development: Children have the benefit to a wide range of headway: Emotional, Mental, and Physical. Enthusiastic change is fulfilled by authentic care and love of a candidly steady system, mental headway through preparing and learning and physical change through stimulation, play, and sustenance.

\section{What is Child Protection?}

UNICEF considers youth confirmation as the shirking of or responding to the event of abuse, misuse, viciousness and nonchalance of children. This joins business sexual misuse, trafficking, adolescent work and dangerous standard practices, for instance, female genital mutilation/cutting and child marriage. Affirmation similarly allows children to have passage to their distinctive benefits of survival, change, advancement and venture. UNICEF keeps up that when kid security misses the mark or is missing youths have a higher peril of death, poor physical and mental prosperity, HIV/AIDS disease, educational issues, movement, vagrancy, vagrancy and poor child raising capacities further not far off.

As demonstrated by the Integrated Child Protection Scheme (ICPS) Child Protection is about keeping kids safe from a threat or saw the risk to their lives or pre-adulthood. It is about seeing that children are exposed and in this way decreasing their feebleness by protecting them from harm and risky circumstances. Child affirmation is about ensuring that adolescents have a security net to depend on upon, and in case they happen to fall through the holes in the system, the structure has the commitment to give the child the critical thought and rebuilding to bring them over into the prosperity net. [23]

\section{Concept of Children's Rights:-}

It is fundamental to understand the distinction between two notions. Children's rights are a strategy of theories or models. They are abilities and some of them are sensible in a formal court, yet they are not 
unmistakable. Security is one of these rights. Notwithstanding, Child Protection is more than an advantage. It is a structure or framework by which the advantages of a child can come to be. The structure contains particular duty bearers, for occasion, the divisions of the association, police, school, typical society, who all have parts to play to guarantee that a children's rights are met, and for the situation that an immature rights are misused that the violator is passed on to esteem and believed be given to the child. Pre-adult security is treatment and what's more preventive. Hazard association needs to hop out at diminishment the danger of infringement of child rights in any given condition or space.

Child security is consequently the techniques through which each other right of a child can be kept up. For example, a child has the advantage to hold up under on a typical child in a family condition. The child assurance structure needs to first make sense of how to guarantee families can make due by giving them when success, get ready, and sustenance forever or at the irrelevant expense. The going with step is to address the necessities of teenagers who have been able to be lost disregarding general sentiment awareness, for the case poor, abandoned, and orphan children. The structure combines the instruments to migrate these young people into mind in families either through adoption or child care or foster care and give these children access to success and get ready associations. Along these lines, the structure is not a solitary organization or single government body it is the interlinking parts of all systems and parts.

\section{Conclusion}

Children develop the nation's precious human resources. The future accomplishment of the nation depends on upon how its children perform and execute. The great poet Milton said, "Youth Shows the man as morning presentations the day". So it is the devotion of the general masses to deal with every pre-adult with a point of view to ensuring full advance of its personality. Children are the future controllers and light bearers of the Society: they are the units of our understanding, social legacy, conviction structures, and rationalities.

Children are genuinely future parts as sensational instructors, specialists, judges, rulers, powers, coordinators, engineers, politicians on whom the entire society set up (rests). Disastrously a broad number of children are obstructed from securing their childhood and right to bearing and thereby they are subjected to exploitation, misuse, and abuse.

Child labor is a complex wealth related issue. In a country where a large number children go to bed hungry, without having a single full dinner of the day, total end of child labor by the basic legal arrangement of activity can never be said to be a sensible recommendation. It may cover the disquietude yet can't cure it. Samuel Johnson opined that, "Desperation is a remarkable adversary to human fulfillment; it certainly destroys flexibility, and it makes a couple of Excellencies impracticable and others to an extraordinary degree troublesome".

\section{Suggestions}

The Government of India other than getting justice the importance of the child in different authorizations can in like manner swing to the going with measures for the welfare of the child: The fissure between their childhood and adulthood can be crossed by giving them stages to enhance their aptitudes for a prevalent business later; the schools should give and redesign the expert capacities of youths other than fundamental preparing to make it worthwhile to children having a spot with the loaded ranges of the overall population. The Government suits Mid-Day Meals in schools and nearby expert direction - a particular measure of expert preparing is starting now given - the enrolment in schools may in like manner addition as going to class will be significant for the child.

Child welfare programs like the Kishori Shakti Yojana (Program for young women) and Rajiv Gandhi Scheme for the fortifying of Adolescent Girls have been pushed by the governing body to empower the young women in expert, life, and wholesome capacities. Enrolment in these undertakings can be intense in putting off the child in taking up work in industry; Schemes for the pre-adult young children can have any sort of impact in the lives of young children. The need is to begin the child into expert guideline after their compulsory preparing. This can be begun with the help of stages which the organization starting now has for the welfare of the children. The stages may be the schools at the common and urban levels where growth in their direction can be given as expert preparing.

The Government of India has moreover dispatched Integrated Child Protection Services Scheme to manage the youth requiring thought and certification. The degree of this framework can be reached out with the help of commonplace and urban adjacent government to professionally get ready adolescents and deferral their employment; and the issue of child work must be taken care of by study this risk in the greater perspective. The Government has begun dares to do thusly by starting different national level tasks like National Rural Employment Guarantee Scheme, Food Security Scheme, National Rural Health Mission, Integrated Child headway Services Scheme Integrated Child Protection Services Scheme et cetera. 
The tenderness of juvenile prompts and is further made by the socio-legal, socio-political and socioreligious circumstances they are in. A child who is constrained or naturally introduced to a circumstance or segregated gathering is at danger for misuse, disregard, and abuse. The absence of a security framework either because of his execution of national laws and programs or the nonappearance of insurance arrangements and enactment additionally renders children powerless. Taking after is a dialog of different security issues concerning children.

\section{References}

[1]. Dr. Bikram Kumar Das (2016), Juvenile Justice System in India, Indian Journal of Research, Volume-5, Issue-5, p.1 [2]. http://plato.stanford.edu/entries/childhood/ Accessed $15^{\text {th }}$ June, 2015

[3]. Locke, John, [EHC] 1959, An Essay Concerning Human Understanding (Volume I), New York: Dover preparations

[4]. http://plato.stanford.edu/entries/childhood/ Accessed $15^{\text {th }}$ June, 2015

[5]. Section 82 and 83 of the Indian Penal Code, 1860

[6]. Article 21-A, Article 45 and Article 51-A (g) of the Constitution of India, The Constitution (86 ${ }^{\text {th }}$ Amendment) Act, 2002, 12 December, 2002

[7]. The Child Labour (Prohibition and Regulation) Act, 1986, Act No. 61 of 1986, 23th December, 1986

[8]. Shreyansh Chouradia (2012), Child Labour: The Burning Predicament In The World, Legal Service of India, http://www.legalserviceindia.com/article/1216-Child-Labour.html /Accessed 20th July, 2016

[9]. Section 2 (c) of the the Motor Transport Workers Act 1961 and Section 2 (b) of the Beedi and Cigar Workers (Conditions of Employment) Act 1966

[10]. Section 109 of the Merchant Shipping Act, 1958 and Section 3 (a) of the Apprentices Act 1961

[11]. Section 2 (b) of the Mines Act, 1952

[12]. Section 2 (a) of the Prohibition of Child Marriage Act, 2006

[13]. Section 3 and 4 of the Indian Majority Act, 1875

[14]. Section 2 (h) of the Juvenile Justice Act, 1986

[15]. Section 2 (k) of the Juvenile Justice Act, 2000

[16]. Section 15 of the Juvenile Justice Act, 2015

[17]. http://www.firstpost.com/india/how-will-the-new-juvenile-justice-act-factor-in-children-recruited-by-naxals-for-heinous-crimes2580330.html /Accessed 23 July, 2016

[18]. http://www.hrln.org/hrln/child-rights/pils-a-cases/1486-apex-court-observed-that-children-are-qsupremely-important-nationalassetq.html\#ixzz4FIZNpL2w / Accessed 23 July, 2016

[19]. Vinod Kumar Tikoo and others,(2013) Assessment of Pattern and Profile of Substance Use among Children in India, NCPCR, New Delhi

[20]. Ibid

[21]. Ibid

[22]. Swagata Raha, How will the new Juvenile Justice Act factor in children recruited by Naxals for 'heinous crimes'? F. India, $12^{\text {th }}$ January, 2016

[23]. Child Line In India, Child Protection \& Child Rights- I- Details, Nanhi Jaan Foundation, Child Protection and Child Rights. 